village, a church, and a pastor. One winter night when a fearful storm was threatened, three Finns (i.e. Lapps) entered the valley and begged shelter in vain of the inhabitants. At last they asked the priest, and he too refused. Then the wrath of the heathen wizards was raised, and they solemnly cursed the valley and doomed it to destruction by the crawling power of the ice, until the glacier reached the lake below. The Lapps were seen no more, but on their disappearing the snow began to fall. The winter was awful. The glacier approached by awful steps, and by degrees engulfed the cursed valley and farms. Nor is the curse yet exhausted, for the glacier creeps down the valley each year, and has yet a mile to go before it reaches its destination in the lake above Ocide. I am no judge of folk-lore, but this weird tale seemed to me a genuine piece of it, and not invented for the occasion, as OIsen gave it half jokingly as the tradition of the district. The farmer who owns the remnant of the doomed valley, wanted then to sell it, as he saw his acres swallowed up each year, but no one will buy. If this tale be genuine, it points to a prolonged advance of the Folgefond, which has led to the tale of the Lapps' curse. Those interested in ice-action will see a fine example of the "Tyssenstrengene," or polished stone fells of Norway, between Odde and the splendid Skjægadals (or Ringedal's) Fos. The rocks are so polished by the ancient ice that a path is made over them by putting rough fir trees down to give a foothold. The ice-polishing on the Grimsel Pass in Switzerland, is a mere nothing to these "Tyssenstrengene."

J. INNES ROGERS

\section{Intelligence in Birds}

OUR English jackdaws are not behind Miss Bird's Japanese erows in at any rate one of the instances of intelligence told by her. Many years ago it was a frequent amusement of ours to watch the encounters between a tame jackdaw and the stable cat. The cat's dinner used to be put down outside the stabledoor, and, .warned by experience, she hastened to dispose of as much as possible before the arrival of the jackdaw. He seldom went directly to the meat in the plate, but attacked the enemy in the rear, settling himself with both feet on her outstretched tail to steady it, and then administering pickaxe blows on it with his beak. Of course it was impossible to stand this, and with a forcible exclamation the cat used to spring away, and Jack took possession of the plate, until our sense of justice obliged us to recall and defend the rightful owner.

E. HUBBARD

March 6

\section{Auroral Display}

I SEE by your number of NATURE, vol. xxy. p. 386 , that an auroral display was witnessed in England on February 20 , between 7 and $8 \mathrm{p} . \mathrm{m}$. A very magnificent one was seen in the Hardanger-fjord on the same evening at the same hour, by a friend of mine, and the Captain of the ss. Folgefonden says he has never seen a finer. Could it have been the same aurora?

Lysefjord near Stavanger, Norway, March 9 W. E. KoCH

\section{ON THE CHEMISTRY OF THE PLANTE AND FAURE ACCUMULATORS}

PART II. - The Charging of the Cell

I N NATURE (vol. xxv. p. 22I) we directed attention principally to the local action that takes place on the negative plate of a Planté or Faure battery. We pointed out the close analogy between zinc coated with spongy copper, and lead coated with spongy peroxide, in their action on water or dilute sulphuric acid; and we showed the importance of the lead sulphate produced in moderating this action. We now propose to treat of the chemical changes involved in the preparation of the cells.

The procedure of Planté in forming his battery is at first sight extremely simple. He takes two coils of lead, separated from one another, and immersed in dilute sulphuric acid; a current is sent through the liquid from one lead plate to the other, and the final result is, that the one becomes covered with a coating of lead peroxide, while hydrogen is given off against the other plate. On the view that the sulphuric acid merely serves to diminish. the resistance, and so facilitate the electrolysis of water, the ready explanation would be given that the two elements of the water are simply separated at the two poles. But it seems more in accordance with the facts of electrolysis, to suppose that the sulphuric acid, $\mathrm{H}_{2} \mathrm{SO}_{4}$, is itself the electrolyte, and that the oxygen results from a secondary chemical reaction. As a matter of fact, if water be employed, no peroxide is formed, but only the hydrated protoxide, even though a current from twenty-four Grove's cells be made use of. The addition of a single drop of sulphuric acid to the water is enough to cause the immediate production of the puce-coloured oxide.

If we take two plates of lead in dilute sulphuric acid, and pass the current from only one Grove's cell, a film of white sulphate, instead of peroxide, makes its appearance on the positive pole, and the action practically ceases very soon. If, however, the current be increased in strength, the sulphate disappears, and peroxide is found in its place. In Planté's procedure, spongy lead, and lead peroxide are indeed found on the respective plates. But, in consequence of the local action which takes place during the periods of repose, lead sulphate will be produced from the peroxide, and afterwards, in the course of the "formation," this must be reduced to metallic lead by the hydrogen.

It may seem at first sight improbable that an almost insoluble salt of the character of lead-sulphate should be decomposed under these circumstances. To test this fact by direct experiment, we covered two platinum plates with lead-sulphate, immersed them in dilute sulphuric acid, and sent a current through. We found not only that the sulphate was reduced by electrolytic hydrogen, but that it was peroxidised by electrolytic oxygen. The white sulphate was, in fact, decomposed to a large extent at each plate, the positive being covered with deep chocolate-ccloured peroxide, the negative with grey spongy lead.

The reaction which takes place in charging a Planté battery may be viewed in two ways. The simplest may be thus expressed in the notation which we have employed in some previous papers. For convenience, the reaction is divided into two stages :-

$$
\begin{aligned}
& \mathrm{Pb}_{x}\left|\begin{array}{l}
\mathrm{SO}_{4} \mathrm{H}_{2} \\
\mathrm{SO}_{4} \mathrm{H}_{2}
\end{array}\right| \mathrm{Pb}_{y}=\mathrm{Pb}_{x-\mathrm{r}}\left|\mathrm{PbO}_{2}\right| \begin{array}{l|l}
\mathrm{SO}_{3} & \mathrm{H}_{2} \\
\mathrm{SO}_{3} & \mathrm{H}_{2}
\end{array} \mid \mathrm{Pb}_{y} . \\
& \text { and } \quad{ }_{2} \mathrm{SO}_{3}+2 \mathrm{H}_{2} \mathrm{O}=2 \mathrm{H}_{2} \mathrm{SO}_{4} \text {. }
\end{aligned}
$$

But it may be that lead-sulphate is always formed in the first instance, and decomposed on the continuation of the current. then

$$
\mathrm{Pb}_{x}\left|\mathrm{SO}_{4} \mathrm{H}_{2}\right| \mathrm{Pb}_{y}=\mathrm{Pb}_{x}-\mathrm{I}\left|\mathrm{SO}_{4} \mathrm{~Pb}\right| \mathrm{H}_{2} \mid \mathrm{Pb}_{y} .
$$

$$
\begin{aligned}
& \mathrm{Pb} x-\mathrm{x}\left|\mathrm{SO}_{4} \mathrm{~Pb}\right| \mathrm{SO}_{4} \mathrm{H}_{2}\left|\mathrm{~Pb}_{y}=\mathrm{Pb}_{x-x}\right| \mathrm{PbO}_{2} \\
& \begin{array}{l|l|l}
\mathrm{SO}_{3} & \mathrm{H}_{2} & \mathrm{~Pb}_{y} .
\end{array} \\
& \text { and } \quad 2 \mathrm{SO}_{3}+2 \mathrm{H}_{2} \mathrm{O}=2 \mathrm{H}_{2} \mathrm{SO}_{4} \text {. }
\end{aligned}
$$

It seems not improbable that both these reactions may take place according to the varying density, or other circumstances of the current. The coating of peroxide interposes a great difficulty in the way of the further oxidation of the metallic lead. Hence Planté needs the successive periods of repose, to admit by local action of the formation of lead-sulphate, and the oxidation of the increasing amounts of finely-divided lead thus brought into the field of action.

To obviate this waste of power and time, Faure covers both plates with red lead, and converts this into spongy peroxide and spongy lead respectively by the current. Now the first thing that happens, when the plates are immersed in the dilute sulphuric acid is a purely chemical action. The minium suffers decomposition according to the formula-

$$
\mathrm{Pb}_{3} \mathrm{O}_{4}+2 \mathrm{H}_{2} \mathrm{SO}_{4}=\mathrm{PbO}_{2}+2 \mathrm{PbSO}_{4}+2 \mathrm{H}_{2} \mathrm{O} \text {. }
$$


But as both the lead sulphate and lead peroxide are insoluble, this takes place mainly at the surface, and requires time to penetrate. Thus in an experiment performed with the object of testing this point, the following amounts of minium were found to be converted into lead sulphate in successive periods of time.

\begin{tabular}{|c|c|c|c|c|}
\hline & $\begin{array}{l}\text { ime. } \\
\text { inutes }\end{array}$ & $\ldots$ & \multicolumn{2}{|c|}{$\begin{array}{l}\text { Minium changed } \\
\text { into sulphate. } \\
\text { I I } 8 \text { per cent. }\end{array}$} \\
\hline 30 & ', & $\ldots$ & $13 \% 7$ & , \\
\hline & & $\cdots$ & $\mathrm{I} 4^{\circ} 6$ & ", \\
\hline 20 & ," & $\ldots$ & I8.I & ," \\
\hline
\end{tabular}

It might happen, and we are told it has happened, that the amount of minium employed has been great enough to abstract the sulphuric acid from solution, leaving only water. In that case water, of course, would be the electrolyte, and there can be little doubt that the lead plate would suffer oxidation in the manner which was described by us some years ago (Chem. Soc. Journ., 1876) in a paper on "Phenomena accompanying the Electrolysis of Water with Oxidisable Electrodes." This paper detailed the results obtained on passing a current from one Grove's cell between two plates of the same metal immersed in pure water. We stated in the case of lead: "The positive electrode showed signs of slight oxidation, and the negative electrode a few small bubbles, in fifteen minutes; a slight cloudiness was then beginning to form, which lafterwards increased; some oxide was found adhering in an hour; and afterwards grey metallic lead, which at the end of twenty-two hours was found to have stretched across to the positive electrode, forming a metallic connection which was so much heated by the passage of the voltaic current that the liquid became warm." We are informed that such lead crystals have sometimes been found in Faure's cells.

Supposing, however, that there is enough and to spare of sulphuric acid, the mixture of lead peroxide and lead sulphate presents a double problem. Were we dealing with peroxide alone, it would be reduced on the one plate at the expense of two molecules of water or sulphuric acid, while at the opposite pole the oxygen would simply be liberated.

$$
\begin{aligned}
& \mathrm{Pb}\left|\mathrm{PbO}_{2}\right| \mathrm{SO}_{4} \mathrm{H}_{2}\left|\mathrm{SO}_{4} \mathrm{H}_{2}\right| \mathrm{PbO}_{2}\left|\mathrm{~Pb}_{y}=\mathrm{Pb}_{x}\right| \\
& \mathrm{PbO}_{2}\left|\mathrm{O}_{2}\right| \mathrm{SO}_{4} \mathrm{H}_{2}\left|\mathrm{SO}_{4} \mathrm{H}_{2}\right| \mathrm{Pb}_{y+\mathrm{r}} \text {. }
\end{aligned}
$$

But as there is always lead sulphate present, this liberated oxygen is mainly used up in oxidating that substance, and it is evident from the following formula that it is theoretically sufficient to peroxidise the two molecules of sulphate-

$$
2 \mathrm{PbSO}_{4}+2 \mathrm{H}_{2} \mathrm{O}+\mathrm{O}_{2}=2 \mathrm{PbO}_{2}+2 \mathrm{H}_{2} \mathrm{SO}_{4} .
$$

These two molecules of $\mathrm{PbSO}_{4}$ are obtained from one molecule of $\mathrm{Pb}_{3} \mathrm{O}_{4}$ (red lead), and it appears that two atoms of oxygen are sufficient to transform this into peroxide. But the corresponding amount of hydrogen (four atoms) by no means suffices to reduce a similar amount of red lead on the other side, for in this case both the peroxide and the sulphate formed by the action of the acid have to be reduced. To accomplish this at least eight atoms of hydrogen will be necessary, and this will demand the electrolysis of an additional two molecules of water or sulphuric acid. It might therefore be expected, a priori, that the minium on the side to be oxidated ought to be twice the amount of that to be reduced.

In order to ascertain what is the real course of procedure, in charging a Faure battery, we took two plates of lead of equal size, and covered each with a known weight of minium, which was almost pure $\mathrm{Pb}_{3} \mathrm{O}_{4}$. We passed a current of known strength, about one Ampère, through the arrangement for many hours, noting the amount of hydrogen gas which was liberated at the one pole, and the amount of oxygen liberated at the other. From the data it was easy to calculate the amount of electrolytic hydrogen and oxygen utilised. We performed the experiment several times, varying the strength of the current and

\begin{tabular}{|c|c|c|c|c|}
\hline \multirow{2}{*}{ Time. } & \multicolumn{2}{|c|}{ Hydrogen. } & \multicolumn{2}{|c|}{ Oxygen. } \\
\hline & Lost. & Absorbẹd. & Lost. & Absorbed. \\
\hline hours. & c.c. & c.c. & c.c. & c.c. \\
\hline $\mathbf{I}$ & Nil & 312 & $\begin{array}{r}\text { Nil } \\
\text { I } 8\end{array}$ & 156 \\
\hline 2 & $"$ & $\begin{array}{l}318 \\
306\end{array}$ & $\begin{array}{l}18 \\
48\end{array}$ & 141 \\
\hline 3 & $"$ & $\begin{array}{l}306 \\
300\end{array}$ & $\begin{array}{l}40 \\
66\end{array}$ & 105 \\
\hline 4 & $"$ & $\begin{array}{l}300 \\
300\end{array}$ & 72 & $\begin{array}{l}84 \\
78\end{array}$ \\
\hline $\begin{array}{l}5 \\
6\end{array}$ & $"_{2}$ & $\begin{array}{l}300 \\
313\end{array}$ & 90 & $\begin{array}{l}78 \\
67\end{array}$ \\
\hline 7 & 5 & $\begin{array}{l}313 \\
295\end{array}$ & 87 & 63 \\
\hline 8 & 3 & $3^{12}$ & 96 & $6 \mathrm{r}$ \\
\hline 9 & 6 & $3 \circ 3$ & 93 & $6 \mathrm{I}$ \\
\hline Io & $2 \mathrm{I}$ & 297 & 99 & 60 \\
\hline I I & 37 & 273 & 99 & $5^{6}$ \\
\hline 12 & Ior & 220 & 105 & 56 \\
\hline 13 & 150 & 158 & 105 & 49 \\
\hline 14 & I 95 & 132 & 105 & 58 \\
\hline 15 & 210 & 92 & 100 & $5^{\mathrm{I}}$ \\
\hline 16 & 228 & 90 & I06 & 53 \\
\hline 17 & 225 & 85 & IOO & 55 \\
\hline 18 & 270 & 66 & 108 & 60 \\
\hline 19 & $26_{4}$ & $5^{1}$ & 108 & 49 \\
\hline 20 & 270 & 50 & I I I & 49 \\
\hline 21 & 273 & 43 & $\mathrm{XI}_{4}$ & 44 \\
\hline 22 & 270 & 30 & 114 & 36 \\
\hline 23 & 276 & 30 & $\mathrm{II}_{4}$ & 39 \\
\hline 24 & 297 & $2 \mathrm{I}$ & 123 & 36 \\
\hline 25 & 309 & 9 & 126 & 33 \\
\hline 26 & 270 & 18 & 120 & 24 \\
\hline 27 & 300 & 18 & 132 & 27 \\
\hline 28 & 309 & II & $13^{8}$ & 22 \\
\hline 29 & 321 & 15 & I 4 I & 27 \\
\hline 30 & 318 & 15 & 147 & 19 \\
\hline \multirow[t]{2}{*}{$3^{I}$} & 300 & 6 & I 35 & 18 \\
\hline & 5230 & 4489 & 3120 & 1737 \\
\hline
\end{tabular}
some other circumstances. The most complete result was as follows :-

The amounts of hydrogen and oxygen capable of being absorbed by the materials on the plates were 4574 and I 294 respectively.

We read the indications of this table in the following way:-At first, both the reduction and oxidation take place very perfectly, with little loss of either of the elements of water. The absorption of the hydrogen proceeds with little diminution, until by far the greater part of the lead peroxide and sulphate are reduced, but the last portions are very slowly attacked, probably because they are imbedded in a mass of reduced lead. On the side that is being oxidated it is otherwise : a considerable waste of oxygen soon shows itself, but nevertheless a continuous slow absorption of that element takes place long after the theoretical amount of it has been fixed. A very small amonnt of this excess is to be attributed, according to our experiments, to the oxidation of the metallic plate itself. But we attribute the greater portion to the local action which must be constantly going on between the peroxide and the lead plate with the formation of sulphate of lead, the sulphate in its turn of course being attacked by the electrolytic oxygen. Thus the excess of oxygen in the fifth column of the above table may be looked on as a measure of the local action which has taken place during the charging, and the figures in the lower portion as roughly indicating its progress from hour to hour. Local action will of course take place at first on the opposite plate, but it requires no more hydrogen to reduce two molecules of lead sulphate, 
than one molecule of lead peroxide, and the possibility of local action gradually diminishes as the reduction proceeds.

All our other experiments told the same story as far as the absorption of hydrogen is concerned, but there are differences on the other plate. In one or two instances, not half of the theoretical amount of oxygen was absorbed. On searching into the circumstances on which this depended, we were unable to arrive at any other conclusion, than that it was connected with the condition of the surface of the lead plate.

Experiments with a current of about two Amperres showed that a larger quantity of both hydrogen and oxygen was fixed in a given time, but there was a larger proportionate loss, especially in the case of oxygen. Fxperiments with a current of about half an Ampère, on the contrary, gave a somewhat less rapid action, but a smaller waste of force through the escape of free gas.

A complete study of the results of these experiments would be instructive, but the following comparisons may suffice to illustrate the points just mentioned. The theoretical amount of oxygen required for the red lead used is about $\mathrm{I} 200 \mathrm{cc}$., and the table shows the length of time in which 300,600 , and $1000 \mathrm{cc}$. were fixed by different strengths of current, together with the accompanying loss.

\begin{tabular}{|c|c|c|c|}
\hline $\begin{array}{l}\text { Strength of } \\
\text { current. }\end{array}$ & $\begin{array}{c}\text { Amount of } \\
\text { oxygen stored. }\end{array}$ & Time. & Loss of oxygen. \\
\hline $\begin{array}{c}\text { Ampères } \\
2 \\
\text { I } \\
\frac{1}{2}\end{array}$ & $\begin{array}{l}\text { c.c. } \\
300 \\
", \\
",\end{array}$ & $\begin{array}{c}\text { hours. } \\
\text { I.5 } \\
2 \\
3 \cdot 8\end{array}$ & $\begin{array}{l}\text { c.c. } \\
174 \\
18 \\
15\end{array}$ \\
\hline $\begin{array}{l}2 \\
I^{\frac{1}{2}}\end{array}$ & $\begin{array}{c}600 \\
, " \\
, "\end{array}$ & $\begin{array}{l}4 \cdot 1 \\
5 \cdot 5 \\
7 \cdot 6\end{array}$ & $\begin{array}{r}617 \\
249 \\
47\end{array}$ \\
\hline $\begin{array}{l}2 \\
1 \\
\frac{1}{2}\end{array}$ & $\begin{array}{c}1000 \\
, "\end{array}$ & $\begin{array}{l}13.9 \\
12.2 \\
16.0\end{array}$ & $\begin{array}{r}3081 \\
900 \\
400\end{array}$ \\
\hline
\end{tabular}

In some cases we mixed the red lead with a little water, and allowed it to dry. In other experiments we mixed it at once with dilute sulphuric acid, but without any particular practical advantage.

The forming of a good secondary battery is a matter evidently depending upon very nice adjustment of conditions. It is but a few of these that we have carefully studied; nevertheless we feel ourselves in a position to make one or two suggestions in regard to the economic aspects of the question. It is evident that the energy stored up in a cell is determined mainly by the amount of peroxide present. This appears to be obtained with the smallest amount of waste when the current is not too strong ; in fact, in our experiments it was obtained when the density of the current was about $6 \frac{1}{2}$ Ampères, calculated on the original surface of the lead plates.

There would seem to be no commensurate advantage in continuing the current after the oxygen has ceased to be absorbed pretty freely, because the presence of some unoxidised sulphate of lead, although it increases the resistance, rather impedes than promotes local action.

On the other hand, however, it is necessary that the reduction of the minium on the opposing plate should be complete, for a mixture of lead peroxide and metallic lead would be peculiarly conducive to the production of lead sulphate, and thus increase the resistance; while if any peroxide should remain, it would diminish the electromotive force of the cell.

It would appear probable, therefore, that the most economical arrangement would be obtained by making the red lead to be hydrogenated much smaller in amount than that to be oxidated. On trying the experiment with only half the quantity, we obtained a most satisfactory result as far as the charging was concerned. How far such an arrangement may be really desirable we hope to consider more fully when we treat of the chemistry of the discharge.

March 9 J. H. GLADSTONE ALFRED TRIBE

\section{THE CHANNEL TUNNEL}

THE two schemes for a tunnel beneath the Channel, on the comparative merits of which a Parliamentary Committee will probably take evidence in the course of the year, are based, like those which have preceded them, chiefly on geological considerations. The Weald of Kent and the Bas-Boulonnais, once in all probability geographically continuous, still constitute a single geological area. The chalk of Calais and Sangatte forms the prolongation of that long range which, striking through Dover, Rochester, and Guildford, to near Basingstoke, is known as the North Downs; while that which strikes the coast south of Boulogne, is continued in Beachy Head, and the long range of the South Downs. The North and South Downs curve gently round, so as to meet towards the west, and similarly the Bas.Boulonnais is inclosed by the meeting of the two ranges on the French coast towards the east.

In both these districts the beds of the chalk dip away from the inclosed area, generally at a gentle angle as at Dover, but sometimes steeply as in the Hog's Back. It is clear from this that the beds which rise to the surface in the Weald and in the Bas-Boulonnais are geologically older than the chalk, and must pass under it laterally. The escarpments of the chalk may thus be compared to the fragmentary walls of an oval dome, the top of which has decayed away. The longer axis of this dome extended approximately east and west.

The sequence of beds from the chalk downwards is as follows ${ }^{1}:-$

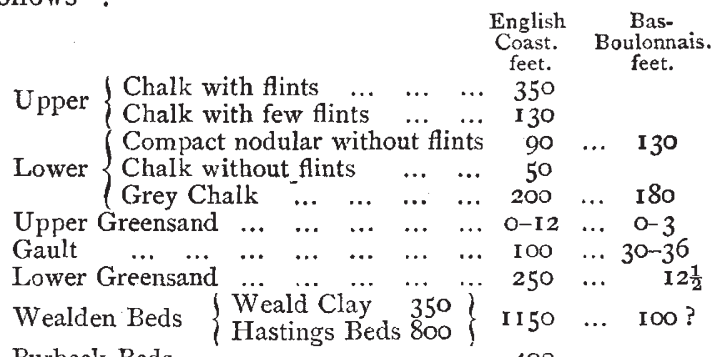

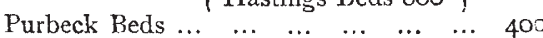

$\left.\begin{array}{lcccccr}\text { Portland Beds } \ldots & \ldots & \ldots & \ldots & \ldots & \ldots & 80 \\ \text { Kimmeridge Clay } & \ldots & \ldots & \ldots & \ldots & \ldots & \text { 1070 } \\ \text { Coralline Oolite } & \ldots & \ldots & \ldots & \ldots & \ldots & 550\end{array}\right\}, \begin{gathered}0 \\ 0\end{gathered}$

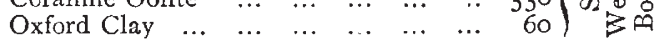

Of these formations the Chalk and Gault have been proved to run with remarkable persistency over a very large area, changing in thickness slowly and uniformly in ascertained directions. It thus was a matter of the utmost probability that they would be found occupying their proper position relative to the other formations, and of their usual dimensions, in the narrow strip occupied by the sea. All doubts on this point were set at rest by the experimental soundings conducted by Sir J. Hawkshaw, and subsequently in greater detail by the French engi neers, MM. Lavalley, Larousse, Potier, and de Lapparen' ; 7,67 I soundings were taken by these gentlemen, and 3,267 specimens of the bottom were brought up, nearly all of which could be identified with certainty as belonging to one or other of the formations named above. A lgeo-

1 The thicknesses of the Chalk on the English coast are taken from the Geol. Survey Memoirs, vol. iv.; those of the Bas-Boulonnais from the French Geol. Survey Memoirs, vol. iv. ; those of the Bas-Boulonnais from the French
Report of 1877 , the thickness of the Lower Chalk being estimated by the Report of 1877 , the thickness of the
position of the lowest beds of flint.

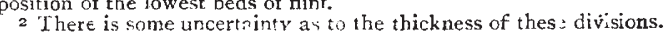

